Prepared in cooperation with the Mississippi Department of Environmental Quality

\title{
Simulation of Water-Management Scenarios for the Mississippi Delta
}

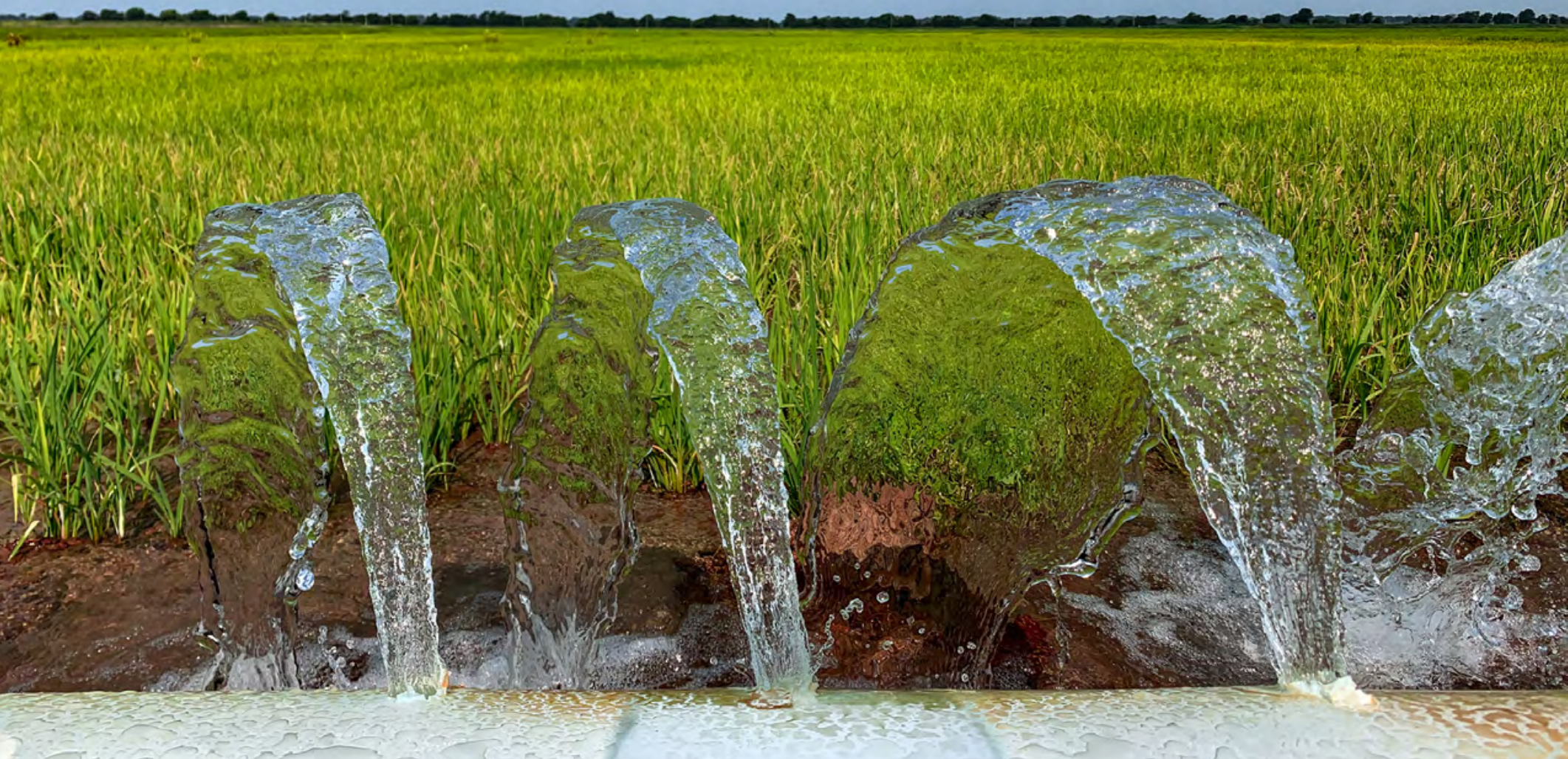

Scientific Investigations Report 2019-5116

U.S. Department of the Interior

U.S. Geological Survey 
Cover photograph: First day of irrigation on a rice field, 2019, Humphreys County, Mississippi. U.S. Geological Survey water-use site 331136090390001 B0331 HUMPHREYS WU (https://waterdata.usgs. gov/nwis/inventory/?site_no=331136090390001\&agency_cd=USGS, accessed December 18, 2019). Photograph by Shane J. Stocks, U.S. Geological Survey. 


\section{Simulation of Water-Management Scenarios for the Mississippi Delta}

By Connor J. Haugh, Courtney D. Killian, and Jeannie R.B. Barlow

Prepared in cooperation with the Mississippi Department of

Environmental Quality

Scientific Investigations Report 2019-5116 


\title{
U.S. Department of the Interior \\ DAVID BERNHARDT, Secretary
}

\author{
U.S. Geological Survey \\ James F. Reilly II, Director
}

U.S. Geological Survey, Reston, Virginia: 2020

For more information on the USGS - the Federal source for science about the Earth, its natural and living resources, natural hazards, and the environment—visit https://www.usgs.gov or call 1-888-ASK-USGS.

For an overview of USGS information products, including maps, imagery, and publications, visit https://store.usgs.gov/.

Any use of trade, firm, or product names is for descriptive purposes only and does not imply endorsement by the U.S. Government.

Although this information product, for the most part, is in the public domain, it also may contain copyrighted materials as noted in the text. Permission to reproduce copyrighted items must be secured from the copyright owner.

Suggested citation:

Haugh, C.J., Killian, C.D., and Barlow, J.R.B., 2020, Simulation of water-management scenarios for the Mississippi Delta: U.S. Geological Survey Scientific Investigations Report 2019-5116, 15 p., https://doi.org/10.3133/sir20195116.

Associated data for this publication:

Haugh, C.J., Killian, C.D., and Barlow, J.R.B., 2020, MODFLOW-2005 model used to evaluate water-management scenarios for the Mississippi Delta: U.S. Geological Survey data release, https://doi.org/10.5066/P9906VM5.

ISSN 2328-031X (print)

ISSN 2328-0328 (online) 


\section{Contents}

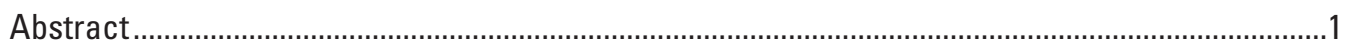

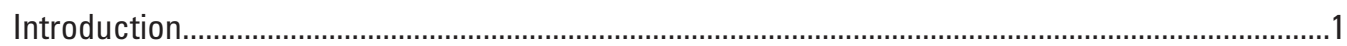

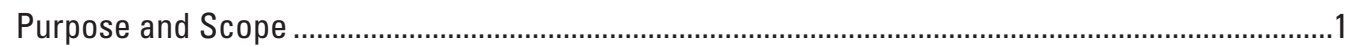

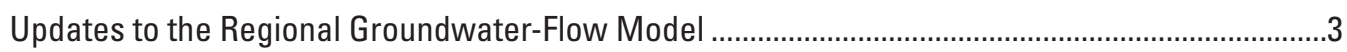

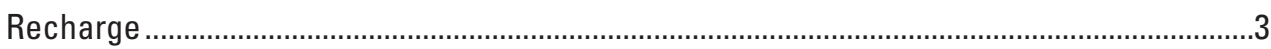

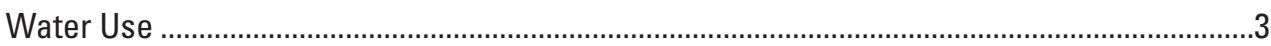

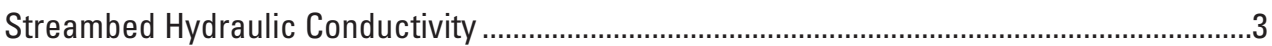

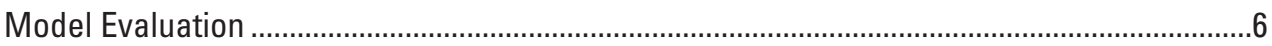

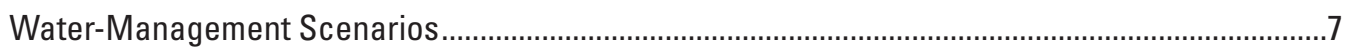

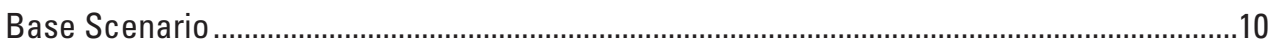

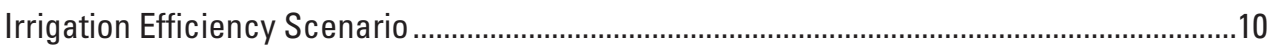

On-Farm Storage and Tailwater-Recovery Scenario ............................................................10

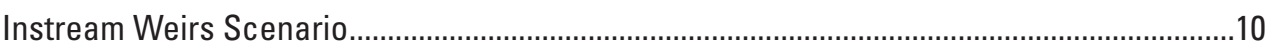

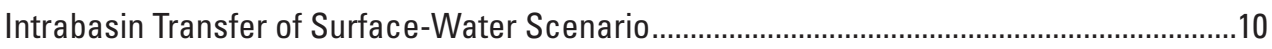

Groundwater-Transfer and Injection Scenario .................................................................13

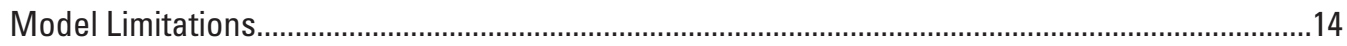

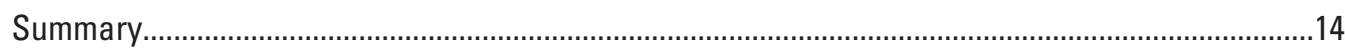

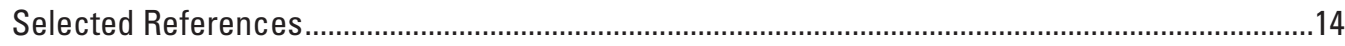

\section{Figures}

1. Map showing location of the Mississippi Delta study area .............................................2

2. Map showing Mississippi Embayment Regional Aquifer Study model domain and surficial geology of the study area and generalized section showing hydrogeologic and geologic units..................................................................................

3. Maps showing water-use distribution in version 2.0 of the Mississippi Embayment Regional Aquifer Study (MERAS) model and water-use distribution in version 2.1 of the MERAS model for the 2006 growing season .......................................5

4. Graphs showing the effects of varying streambed hydraulic conductivity on simulated streambed leakage and simulated water levels ...............................................6

5. Scatter plot showing observed versus simulated water levels for Mississippi Embayment Regional Aquifer Study model versions 2.0 and 2.1 .

6. Maps showing locations of the water-management scenarios: irrigation efficiency, on-farm storage and tailwater recovery, instream weirs, surface-water transfer, and groundwater transfer and injection

7. Hydrographs showing water-level change for each scenario: irrigation efficiency, on-farm storage and tailwater recovery, instream weirs, surface-water transfer, and groundwater transfer and injection 


\section{Tables}

1. Changes in water-level residual statistics between Mississippi Embayment Regional Aquifer Study model versions 2.0 and 2.1 .

2. Summary of selected alternative water-management scenario assumptions and results within area of interest in the Mississippi Delta

\section{Conversion Factors}

U.S. customary units to International System of Units

\begin{tabular}{|c|c|c|}
\hline Multiply & By & To obtain \\
\hline \multicolumn{3}{|c|}{ Length } \\
\hline foot $(\mathrm{ft})$ & 0.3048 & meter $(\mathrm{m})$ \\
\hline mile (mi) & 1.609 & kilometer $(\mathrm{km})$ \\
\hline \multicolumn{3}{|c|}{ Area } \\
\hline acre & 4,047 & square meter $\left(\mathrm{m}^{2}\right)$ \\
\hline acre & 0.4047 & hectare (ha) \\
\hline acre & 0.4047 & square hectometer $\left(\mathrm{hm}^{2}\right)$ \\
\hline acre & 0.004047 & square kilometer $\left(\mathrm{km}^{2}\right)$ \\
\hline square foot $\left(\mathrm{ft}^{2}\right)$ & 929.0 & square centimeter $\left(\mathrm{cm}^{2}\right)$ \\
\hline square foot $\left(\mathrm{ft}^{2}\right)$ & 0.09290 & square meter $\left(\mathrm{m}^{2}\right)$ \\
\hline square mile $\left(\mathrm{mi}^{2}\right)$ & 2.590 & square kilometer $\left(\mathrm{km}^{2}\right)$ \\
\hline \multicolumn{3}{|c|}{ Volume } \\
\hline gallon (gal) & 3.785 & liter $(\mathrm{L})$ \\
\hline gallon (gal) & 0.003785 & cubic meter $\left(\mathrm{m}^{3}\right)$ \\
\hline gallon (gal) & 3.785 & cubic decimeter $\left(\mathrm{dm}^{3}\right)$ \\
\hline million gallons (Mgal) & 3,785 & cubic meter $\left(\mathrm{m}^{3}\right)$ \\
\hline acre-foot (acre-ft) & 1,233 & cubic meter $\left(\mathrm{m}^{3}\right)$ \\
\hline \multicolumn{3}{|c|}{ Flow rate } \\
\hline acre-foot per day (acre-ft/d) & 0.01427 & cubic meter per second $\left(\mathrm{m}^{3} / \mathrm{s}\right)$ \\
\hline acre-foot per year (acre-ft/yr) & 1,233 & cubic meter per year $\left(\mathrm{m}^{3} / \mathrm{yr}\right)$ \\
\hline cubic foot per second $\left(\mathrm{ft}^{3} / \mathrm{s}\right)$ & 0.02832 & cubic meter per second $\left(\mathrm{m}^{3} / \mathrm{s}\right)$ \\
\hline gallons per minute (gal/min) & 0.06308 & liters per second \\
\hline \multicolumn{3}{|c|}{ Hydraulic conductivity } \\
\hline foot per day $(\mathrm{ft} / \mathrm{d})$ & 0.3048 & meter per day $(\mathrm{m} / \mathrm{d})$ \\
\hline \multicolumn{3}{|c|}{ Hydraulic gradient } \\
\hline foot per mile ( $\mathrm{ft} / \mathrm{mi})$ & 0.1894 & meter per kilometer $(\mathrm{m} / \mathrm{km})$ \\
\hline
\end{tabular}

\section{Datum}

Horizontal coordinate information is referenced to the North American Datum of 1983 (NAD 83). 


\title{
Simulation of Water-Management Scenarios for the Mississippi Delta
}

\author{
By Connor J. Haugh, Courtney D. Killian, and Jeannie R.B. Barlow
}

\section{Abstract}

To compare the effectiveness of proposed alternative water-supply scenarios on future water availability in the Mississippi Delta, the U.S. Geological Survey and the Mississippi Department of Environmental Quality are collaborating on the update and enhancement of an existing regional groundwater-flow model of the area. Through this collaboration, the model has been updated to include boundary conditions through March 2014 with the most recent wateruse data, precipitation and recharge data, and streamflow and water-level observation data. The updated model has been used to evaluate selected alternative water-supply scenarios to determine relative effects on the Mississippi River Valley alluvial aquifer. Alternative water-supply options evaluated in this report include: (1) irrigation efficiency, (2) on-farm storage and tailwater recovery, (3) instream weirs to increase surface-water availability, (4) intrabasin transfer of surface water, and (5) groundwater transfer and injection. A relative comparison approach was used to calculate the simulated water-level response caused by each scenario. Water-level response is the difference between water levels simulated by the alternative water-supply scenario and those simulated by a base or "no action" scenario. Water-level response in the alluvial aquifer varied for each scenario based on the location, magnitude, and (or) adoption rates of the simulated alternative water-supply option. The groundwater transfer and injection scenario showed the largest water-level response.

\section{Introduction}

The largest agricultural region within Mississippi is the northwestern Mississippi River alluvial plain, locally referred to as the "Delta" (Economic Research Service, U.S. Department of Agriculture, 2010) (fig. 1). Approximately 9,290 million gallons per day (Mgal/d) of water are withdrawn from the Mississippi River Valley alluvial aquifer in Mississippi (alluvial aquifer), which makes it the most used aquifer in the State (Maupin and Barber, 2005) (fig. 1). Although the alluvial aquifer has a large reserve, it is finite, and evidence indicates declining water levels with the largest declines in the central Delta area (Arthur, 2001; Barlow and Clark, 2011). Water-level declines also have resulted in decreases in baseflow in many Delta streams, most notably in the Big Sunflower River (Barlow and Clark, 2011, p. 6) to the extent that in the absence of rainfall or irrigation return flow, some stream reaches are dry during the summer months (Barlow and Clark, 2011, p. 6).

Agriculture, the dominant land use in the Delta, is an integral economic contributor and is the major category of water use. Presently (2019), the Delta relies primarily on groundwater from the alluvial aquifer for irrigation; historically, surface water also was used as a source of irrigation. Several alternative water-supply scenarios have been proposed to address sustainability of water resources in the Delta.

To compare the effectiveness of proposed alternative water-supply scenarios on future water availability in the Mississippi Delta, an existing regional groundwater-flow model of the area developed by Clark and Hart (2009) was updated and enhanced. Simulation models of the hydrologic system are useful decision-support tools that assist planners in evaluating water-management scenarios and optimizing monitoring efforts to provide data where and when they are most needed.

\section{Purpose and Scope}

Using an existing calibrated regional groundwater-flow model (Clark and Hart, 2009), the U.S. Geological Survey (USGS), in cooperation with the Mississippi Department of Environmental Quality (MDEQ), evaluated five primary water-management scenarios for the alluvial aquifer underlying the Delta in northwestern Mississippi. The five scenarios are (1) irrigation efficiency, (2) on-farm storage and tailwater recovery, (3) instream weirs to increase surface-water availability, (4) intrabasin transfer of surface water to increase surface-water availability, and (5) groundwater transfer and injection. Each scenario was analyzed by simulating the effects on aquifer water levels over a 50-year period and comparing the water-level response relative to a base scenario. Waterlevel response is the difference between water levels simulated by the alternative-supply scenario and those simulated by a base-case or "no action" scenario. The purpose of this report is 


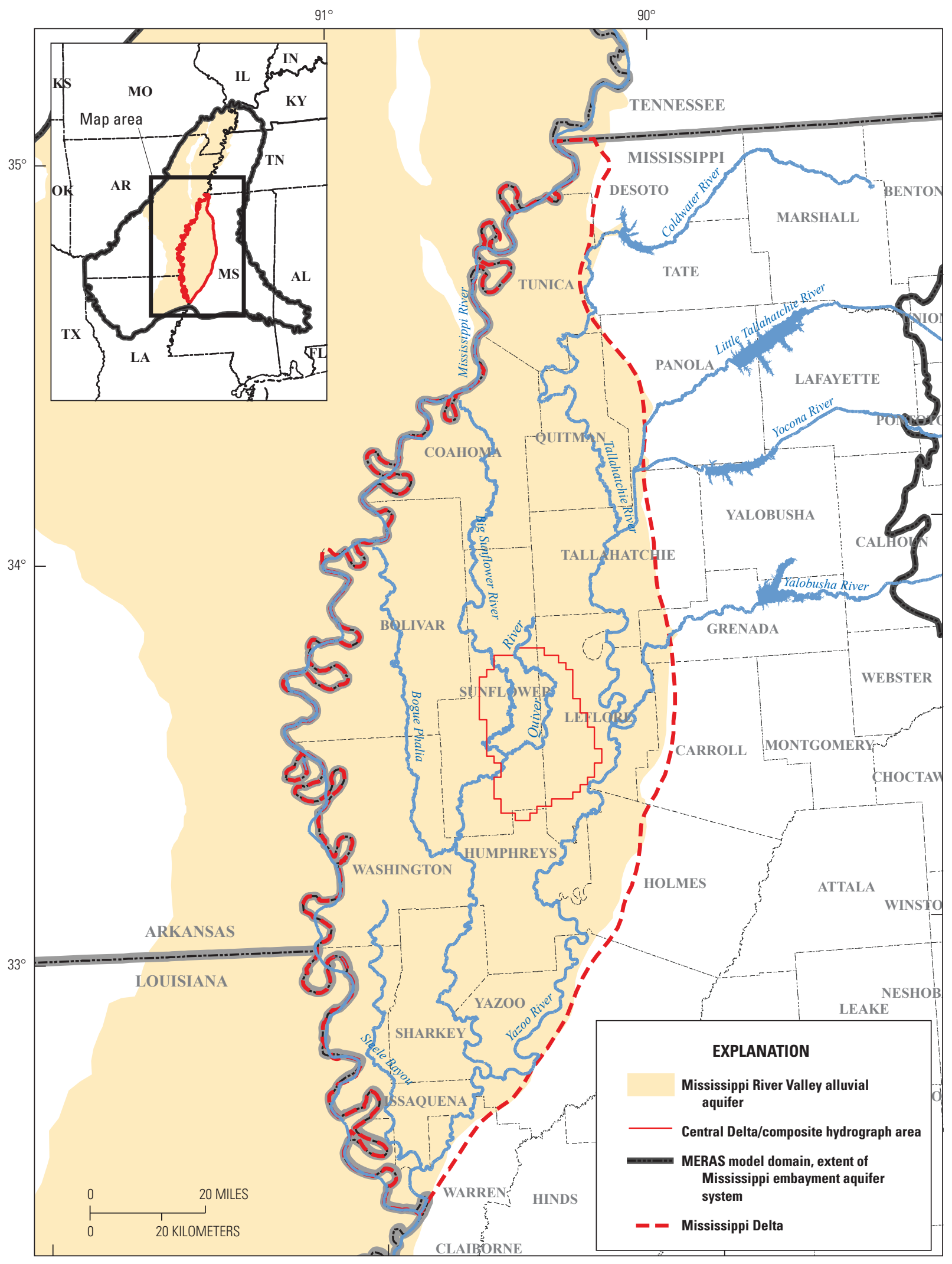

Figure 1. Location of the Mississippi Delta study area. 
to document updates to the model and the results of the model simulations to aid MDEQ in the better understanding of the effects of the various water-management scenarios proposed for the Delta. All data and files used to support the updated model are available from Haugh and others (2020).

\section{Updates to the Regional Groundwater-Flow Model}

As part of the Mississippi Embayment Regional Aquifer Study (MERAS), the USGS developed a large-scale regional groundwater-flow model covering the entire Mississippi embayment and extending through the primary drinkingwater aquifers of the embayment (figs. 1 and 2). This model was constructed using MODFLOW-2005, a software package developed by the USGS (Harbaugh, 2005). The construction and calibration of the original MERAS model (version 1.0) is documented in Clark and Hart (2009). The model calibration period extends from January 1, 1870, to April 1, 2007, for a total of 137 years and 69 stress periods. The first stress period is simulated as steady state to represent predevelopment conditions. Stress periods 2 through 27 are variable in length to reflect embayment-wide changes in groundwater withdrawals. Stress periods 28 (beginning in 1986) through 69 are each 6 months in length to reflect spring-summer (April-September) and fall-winter (October-March) conditions related to irrigation (Clark and Hart, 2009). The MERAS model was further enhanced in 2013 (MERAS model version 2.0) with some modifications to water-use estimates and refined parameter estimation of select aquifer properties by use of pilot points (Clark and others, 2013).

Several updates were made to the MERAS flow model for this study (MERAS model version 2.1), including adding additional stress periods to extend the model through March 31,2014, and a refinement of agricultural water use in the Delta. Fourteen additional stress periods, each 6 months in length (stress periods 70 through 83 ), were added to continue the seasonal stresses related to irrigation and extend the simulation period.

\section{Recharge}

Recharge for the additional stress periods was estimated from monthly precipitation data (PRISM Climate Group, 2015) summed for the stress periods. Recharge was estimated from the precipitation data by using the same zones and multipliers from the original MERAS model (Clark and Hart, 2009).

\section{Water Use}

Agricultural water-use values for the Delta were updated and refined for stress periods 60 (beginning April 1, 2002) through 83 (March 31, 2014). The update includes the last 10 stress periods from the previous MERAS model (version 2.0) plus the 14 stress periods added with this update. The previous model used a county-wide average value estimated every 5 years for agricultural water-use data (fig. $3 A$ ). The updated MERAS model (version 2.1) uses agricultural water-use data estimated at the same scale as the model, a 1-mile (mi) by 1-mi grid cell, on a seasonal basis (seasonal water-use data furnished by Yazoo Mississippi Delta Joint Water Management District [2016; Massey and others, 2017; fig. 3B]). Water use for the added stress periods (70-83) for wells outside the Delta were assumed to continue at the 2006-07 rates as represented by stress periods 68 and 69 .

\section{Streambed Hydraulic Conductivity}

Streambed hydraulic-conductivity values in version 2.1 of the model remained mostly unchanged from those in version 2.0 of the model, except for one reach of the Tallahatchie River in Leflore County, Miss. Streambed hydraulic conductivity, specifically the streambed hydraulic conductivity of the Tallahatchie River, is an important parameter in the groundwater transfer and injection scenario because groundwater is pumped from wells adjacent to the Tallahatchie River in that scenario. If the streambed hydraulic conductivity is high enough such that the Tallahatchie River is well connected with the aquifer, then streambed leakage of water from the river would provide a source of water to the aquifer and therefore to pumping wells adjacent to the river.

Streambed hydraulic conductivity was treated as a regional parameter within large river basins during the MERAS model calibration (Clark and Hart, 2009; Clark and others, 2013). Few data on streambed hydraulic conductivity were available at the time of the initial MERAS model development. The calibrated value of streambed hydraulic conductivity for the Tallahatchie River in MERAS model (version 2.0) is 0.2458 foot per day ( $\mathrm{ft} / \mathrm{d}$ ). To investigate the effect of streambed hydraulic conductivity on streambed leakage and aquifer water levels in the groundwater transfer and injection scenario, three model (version 2.1) simulations were run, assuming the streambed hydraulic conductivity in the reach of the Tallahatchie River near Leflore County, Miss., is $0.2458 \mathrm{ft} / \mathrm{d}, 2.2458 \mathrm{ft} / \mathrm{d}$, and $24.58 \mathrm{ft} / \mathrm{d}$. The output at a model cell (layer 2, row 261, column 218) that contains the Tallahatchie River and a proposed pumping well indicates that streambed leakage increases with higher streambed hydraulic conductivity. At the end of a 50-year simulation period, streambed leakage varied from about 3.9 cubic feet per second $\left(\mathrm{ft}^{3} / \mathrm{s}\right)$ to about $23 \mathrm{ft}^{3} / \mathrm{s}$ with streambed hydraulic-conductivity values of $0.2485 \mathrm{ft} / \mathrm{d}$ and $24.85 \mathrm{ft} / \mathrm{d}$, respectively (fig. $4 A$ ). Additionally, simulations with higher streambed leakage 
$\boldsymbol{A}$

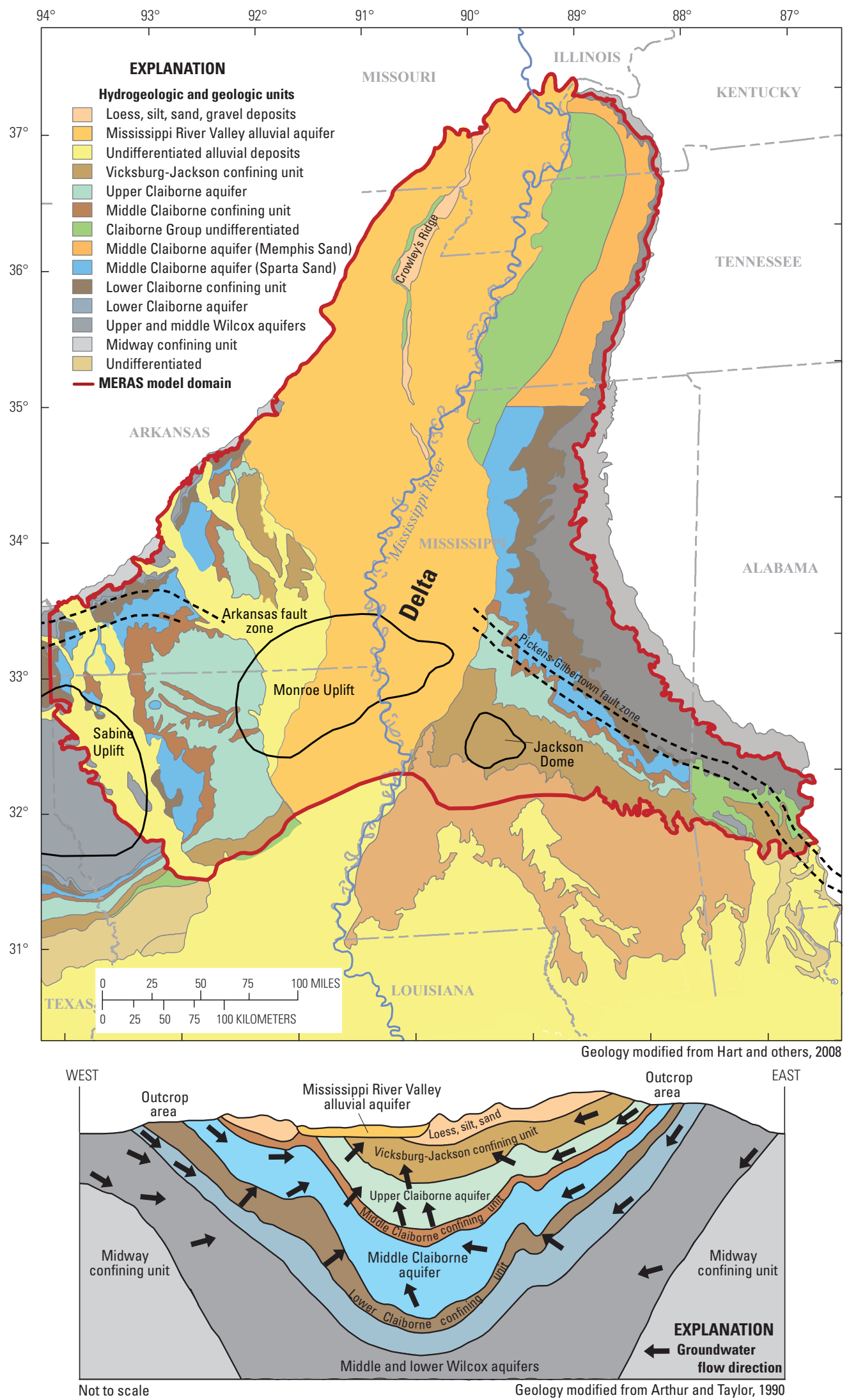

Figure 2. A, Mississippi Embayment Regional Aquifer Study (MERAS) model domain and surficial geology of the study area and $B$, hydrogeologic and geologic units. 
$91^{\circ}$

$90^{\circ}$

$91^{\circ}$

$90^{\circ}$

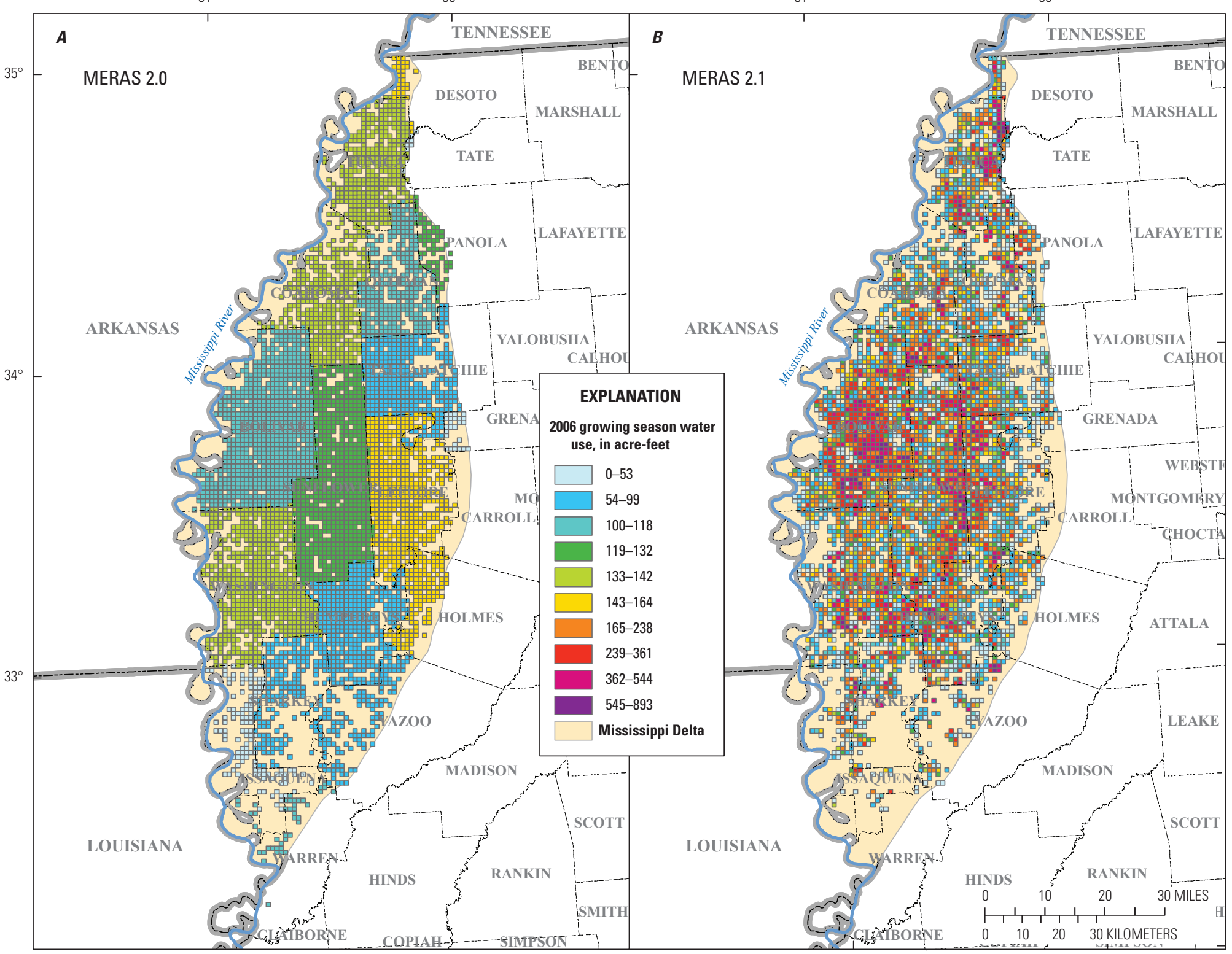

Figure 3. $A$, Water-use distribution in version 2.0 of the Mississippi Embayment Regional Aquifer Study (MERAS) model (Clark and Hart, 2009) and $B$, water-use distribution in version 2.1 of the MERAS model for the 2006 growing season. 

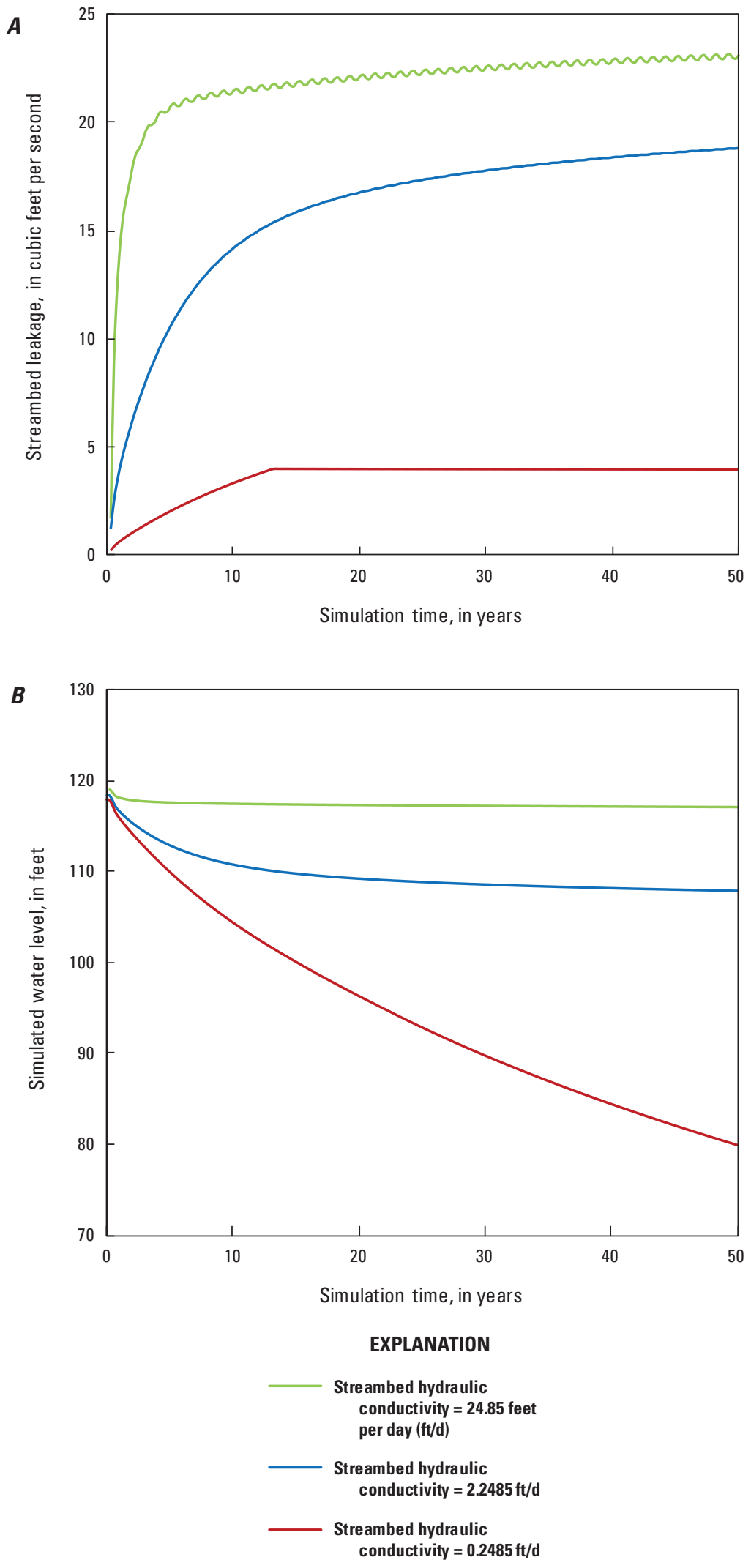

Figure 4. The effects of varying streambed hydraulic conductivity on $A$, simulated streambed leakage and $B$, simulated water levels. indicate less water-level decline in the aquifer as the river provides a source of water to the wells, thus reducing the water removed from aquifer storage (fig. $4 B$ ).

Recent waterborne geophysical datacollection efforts along the Tallahatchie River indicate variations in the streambed material that can affect the streambed hydraulic conductivity (Miller and others, 2016a, b). The geophysical data indicate that the apparent streambed hydraulic conductivities within the area where the groundwater transfer and injection scenario is simulated are relatively higher than those in the rest of the Tallahatchie River (Miller and others, 2016a, b). Therefore, streambed hydraulic conductivity for the reach of the Tallahatchie River where the groundwater transfer and injection scenario is simulated was increased from the calibrated value of $0.2458 \mathrm{ft} / \mathrm{d}$ to $2.2458 \mathrm{ft} / \mathrm{d}$ in the MERAS model version 2.1.

\section{Model Evaluation}

To evaluate if the updates to the model, particularly the agricultural water-use updates for the Delta, improved the model calibration, water-level fit statistics were calculated. The average residual, root mean square error (RMSE), and the sum of squares between the observed and simulated water levels in the Delta for the stress periods that were updated and common to version 2.0 and 2.1 (stress periods 60-69) were calculated (table 1). For these stress periods, there were 1,291 water-level observations from 295 wells (fig. 5). The average water-level residual from the previous MERAS model (version 2.0) to the updated MERAS model (version 2.1) decreased 0.90 foot (ft) from $5.92 \mathrm{ft}$ to $5.02 \mathrm{ft}$, and the RMSE decreased $0.76 \mathrm{ft}$, indicating that the updated water-use values improved the model fit. 


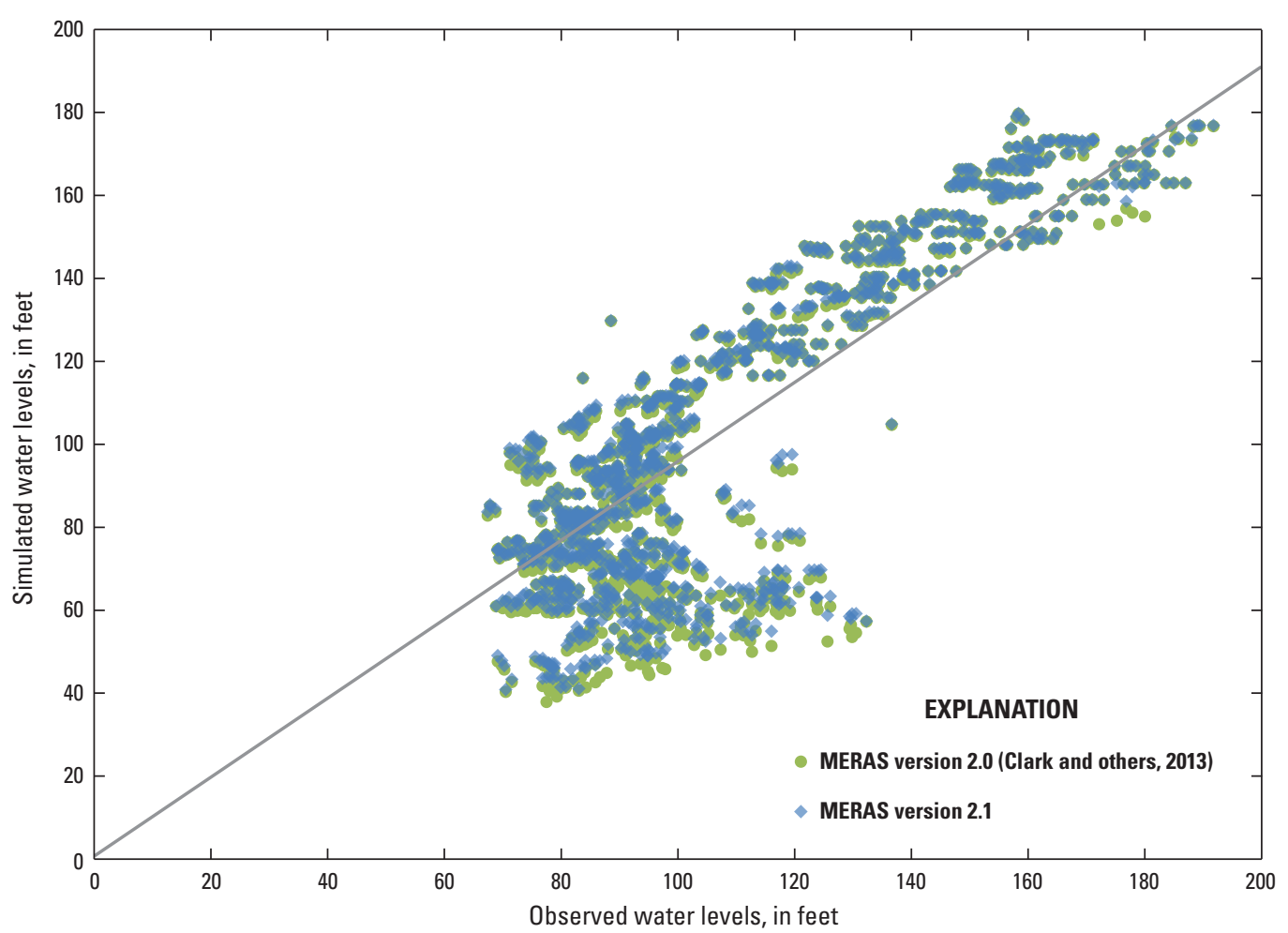

Figure 5. Observed versus simulated water levels for Mississippi Embayment Regional Aquifer Study (MERAS) model versions 2.0 and 2.1. water-level change over time, a "composite hydrograph area" encompassing 283 square miles $\left(\mathrm{mi}^{2}\right)$ was defined near the center of the Delta in an area most affected by waterlevel declines (fig. 1), hereafter referred to as the central Delta area. Within the central Delta area, the average water level was calculated for each stress period and reported as a single hydrograph showing the average water level over time.

Information for each scenario was aggregated and assessed by using a participatory model development approach. An initial workshop on March 19, 2015, brought together stakeholders and technical experts with respect to irrigation and alternative water-supply options in the Delta to

\section{Water-Management Scenarios}

Five water-management scenarios, each with several sub-scenarios, were analyzed. The five scenarios are (1) irrigation efficiency, (2) on-farm storage and tailwater recovery, (3) instream weirs to increase surface-water availability, (4) intrabasin transfer of surface water to increase surface-water availability, and (5) groundwater transfer and injection. The locations of operation for each scenario are shown in figure 6. The first four scenarios decrease groundwater withdrawals through either irrigation efficiency or by providing or enhancing a surface-water resource (figs. $6 A-6 D$ ). The last scenario increases groundwater availability through groundwater transfer (fig. $6 E$ ). For the purpose of computing an average assess all known alternative water-supply options and the amount of data or information available for each option. Alternative water-supply options were selected for model scenario development if enough information or data were available to develop a scenario and if the model was sufficient for representing the scenario. Selected scenarios were then developed through several iterative meetings with the respective technical experts. Once the technical experts approved of the inputs and outputs for their respective scenario, the results from each scenario were shared with various stakeholder groups in the Delta to solicit feedback. The scenarios and results presented in the following sections are the outcome of this participatory model development process.

Table 1. Changes in water-level residual statistics between Mississippi Embayment Regional Aquifer Study (MERAS) model versions 2.0 and 2.1.

\begin{tabular}{|c|c|c|c|c|c|c|}
\hline Model version & $\begin{array}{l}\text { Minimum } \\
\text { observed water } \\
\text { level (feet) }\end{array}$ & $\begin{array}{c}\text { Maximum } \\
\text { observed water } \\
\text { level (feet) }\end{array}$ & $\begin{array}{c}\text { Range in } \\
\text { observed water } \\
\text { levels (feet) }\end{array}$ & $\begin{array}{c}\text { Average residual } \\
\text { (feet) }\end{array}$ & $\begin{array}{l}\text { Root mean } \\
\text { square error } \\
\text { (feet) }\end{array}$ & $\begin{array}{l}\text { Sum of squares } \\
\text { (square feet) }\end{array}$ \\
\hline MERAS 2.0 & 67.40 & 191.75 & 124.35 & 5.92 & 21.48 & 595,458 \\
\hline MERAS 2.1 & 67.40 & 191.75 & 124.35 & 5.02 & 20.71 & 553,825 \\
\hline Change & not applicable & not applicable & not applicable & -0.90 & -0.76 & $-41,633$ \\
\hline
\end{tabular}



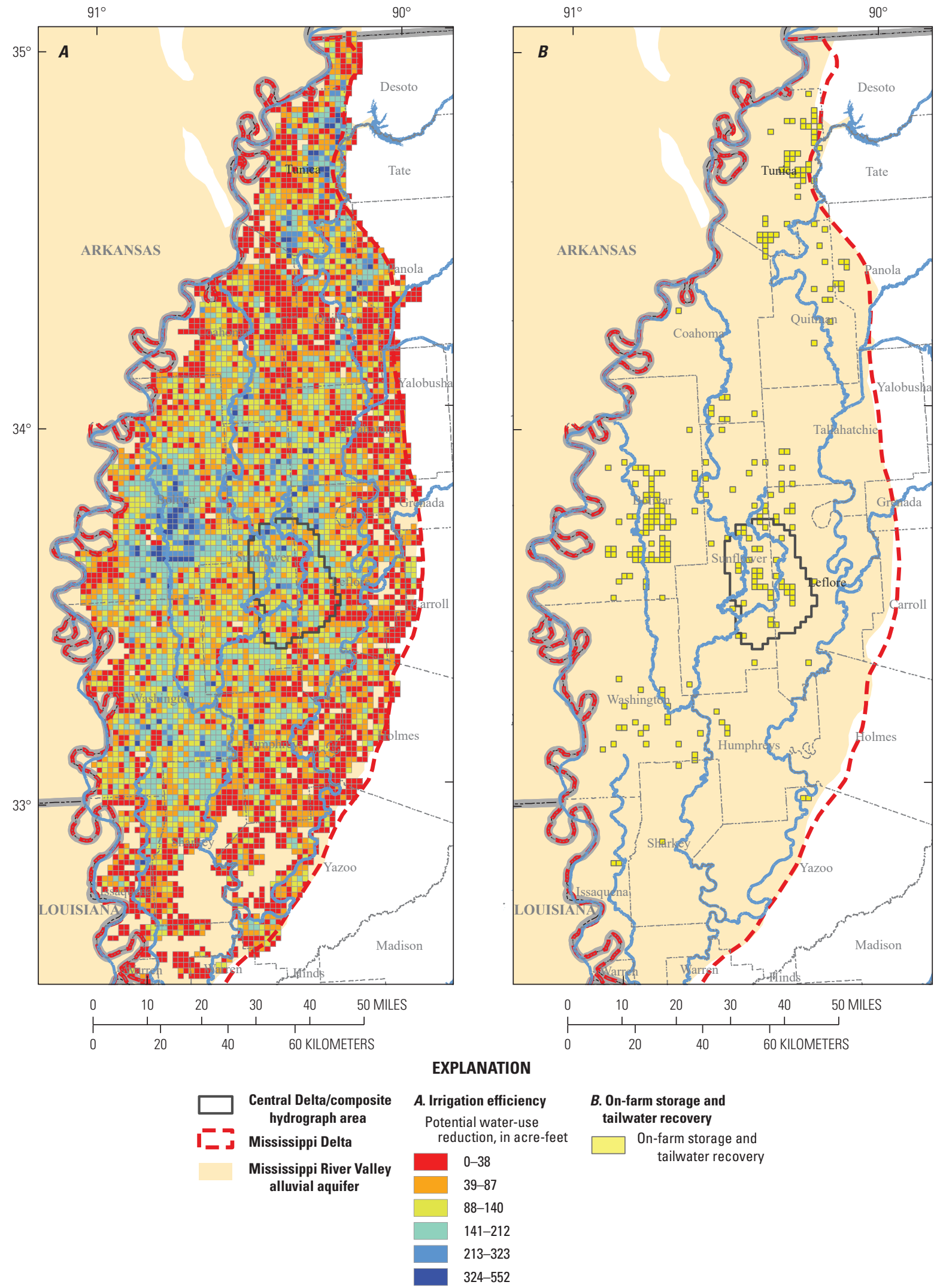

Figure 6. Locations of the water-management scenarios: $A$, irrigation efficiency, $B$, on-farm storage and tailwater recovery, $C$, instream weirs, $D$, surface-water transfer, and $E$, groundwater transfer and injection. 

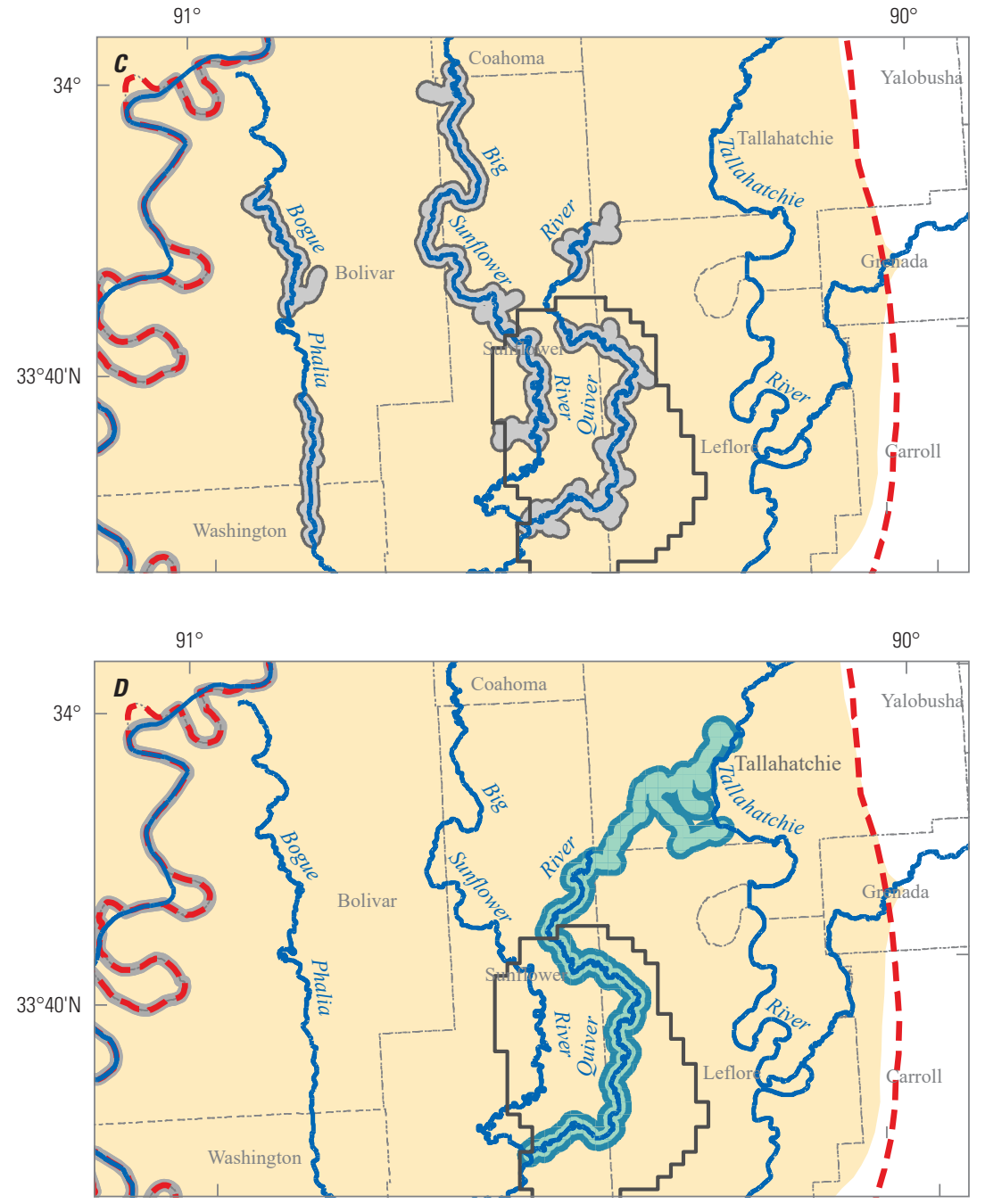

EXPLANATION

Central Delta/composite hydrograph area

I-J Mississippi Delta

Mississippi River Valley alluvial aquifer

\section{Instream weirs}

1/2-mile service area

3/4-mile service area

D. Intrabasin transfer of surface water

1/2-mile service area

1-mile service area

E. Groundwater transfer and injection

$\square$ Extraction cells

Injection cells

A USGS streamgage 07281600

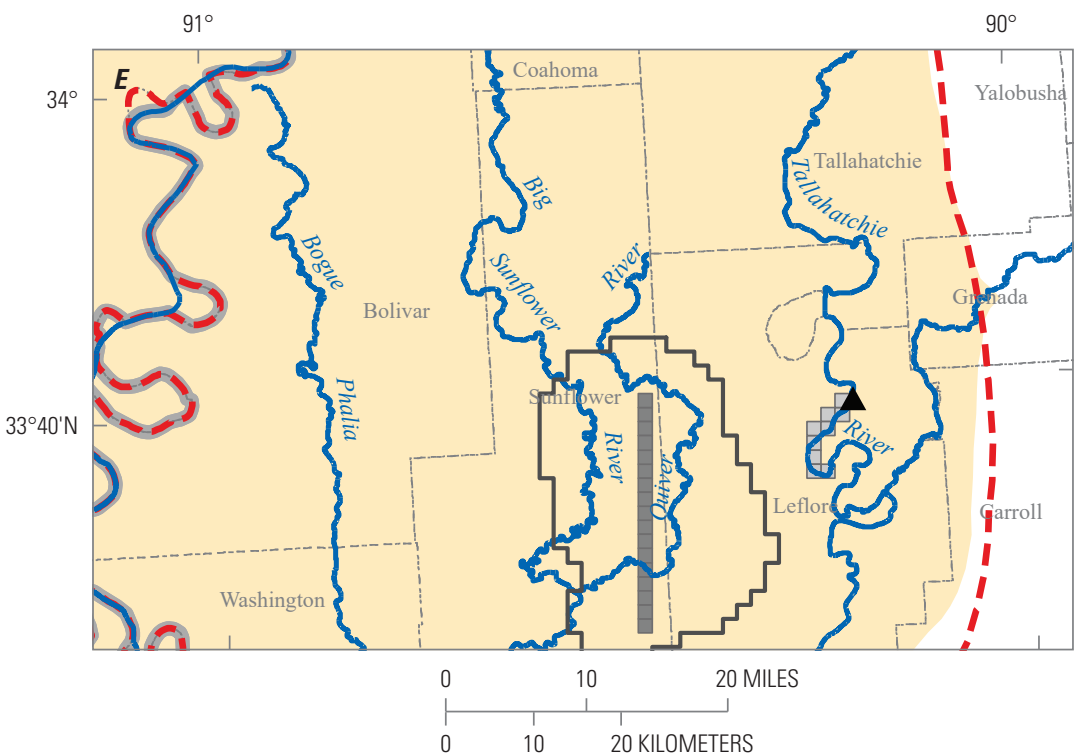

Figure 6. - Continued 


\section{Base Scenario}

The base scenario simulates 50 years by using seasonal 6-month stress periods. The water-use stresses are assumed to remain unchanged from 2013 rates as represented by stress periods 82 and 83 . The recharge rate is set at a constant average annual value. The primary purpose of the base scenario is not to predict future conditions in the aquifer but to provide a standard scenario against which alternate water-management scenarios can be compared.

Figure 7 shows the simulated water-level changes over the central Delta area for the 50-year simulation period. The total change or decline in the average water level over the 50 -year simulation is about $35 \mathrm{ft}$ (fig. 7). Seasonal fluctuations in the water levels related to groundwater withdrawals for irrigation can be noted in the hydrographs.

\section{Irrigation Efficiency Scenario}

The irrigation efficiency scenario assumes that adopting more efficient irrigation techniques will reduce water use. This scenario assumes a 28-percent reduction in water use for rice and soybean irrigation, a 40-percent reduction for corn irrigation, and no reduction for cotton irrigation (fig. 6A). The percentage of reduction in irrigation of crops was recommended by Jason Krutz, Mississippi State University Delta Research and Extension Center (written commun., 2016). This scenario was analyzed with two sub-scenarios - one where the irrigation efficiency was applied throughout the Delta and one where the irrigation efficiency was only applied to the central area of the Delta. The total change or decline in the average water level over the 50-year simulation for the scenario in which irrigation efficiency was applied throughout the Delta is about $20 \mathrm{ft}$, or $15 \mathrm{ft}$ less than the water-level decline of $35 \mathrm{ft}$ for the base scenario (fig. $7 A$; table 2). The total change or decline in the average water level over the 50-year simulation for the scenario in which irrigation efficiency was applied only to the central area of the Delta is about $24 \mathrm{ft}$, or $11 \mathrm{ft}$ less than the water-level decline of $35 \mathrm{ft}$ for the base scenario (fig. $7 A$; table 2).

\section{On-Farm Storage and Tailwater-Recovery Scenario}

The on-farm storage and tailwater-recovery scenario assumes reduction in water use by reusing water captured through tailwater recovery systems or using water from onfarm storage ponds. Tailwater recovery systems catch irrigation runoff and rainfall runoff from the fields and return it to be used for irrigation. The scenario assumes these practices would be implemented at 250 sites, each serving an area of $0.25 \mathrm{mi}^{2}$ (fig. $6 B$ ). Model grid locations were chosen by ordering all Delta grid cells by water use and selecting the 250 grid cells with the highest water use.
This scenario is analyzed with three sub-scenarios depending on the level of water-use reduction assumed. For a given $1 / 4-\mathrm{mi}^{2}$ location, water-use reductions are assumed to be 25 percent with only tailwater recovery, 50 percent with a mix of tailwater recovery and on-farm storage, and 75 percent if tailwater recovery and on-farm storage are fully implemented at a site. The percentage of reduction in water use was recommended by Paul Rodrigue (U.S. Department of Agriculture, Natural Resources Conservation Service, written commun., 2016). The total decline in the average water level over the 50 -year simulation for this scenario ranges from about 32 to $34 \mathrm{ft}$, or 1 to $3 \mathrm{ft}$ less than the decline of $35 \mathrm{ft}$ for the base scenario, depending on the level of water-use reduction assumed (fig. 7B; table 2).

\section{Instream Weirs Scenario}

The instream weirs scenario assumes that 10 weirs can be built on the Bogue Phalia, Big Sunflower River, and Quiver River to increase the amount of available surface water, thus decreasing the need for groundwater pumping (Dave Johnson, U.S. Army Corps of Engineers, Vicksburg District, written commun., 2016; fig. 6C). This scenario was analyzed with six sub-scenarios representing three different rates of adoption and two different areas of availability adjacent to the impounded stream reach. The rates of adoption were assumed to be either 100,66 , or 33 percent. The impounded surface-water source was assumed to be available within either a $1 / 2$ - $\mathrm{mi}$ or $3 / 4$-mi buffer around the impounded stream reach. A sufficient supply of water was assumed for all sub-scenarios.

The total change or decline in the average water level over the 50-year simulation for this scenario, assuming availability within a half mile of an impoundment, ranges from about 23 to $31 \mathrm{ft}$, or 4 to $12 \mathrm{ft}$ less than the decline of $35 \mathrm{ft}$ for the base scenario, depending on the adoption rate assumed (fig. $7 C$; table 2). The total change or decline in the average water level over the 50 -year simulation for the scenario, assuming availability within $3 / 4$ of a mile of an impoundment, ranges from about 18 to $29 \mathrm{ft}$, or 6 to $17 \mathrm{ft}$ less than the decline of $35 \mathrm{ft}$ for the base scenario, depending on the rate of adoption (fig. $7 C$; table 2).

\section{Intrabasin Transfer of Surface-Water Scenario}

The intrabasin transfer of surface-water scenario assumes that water can be diverted from the Tallahatchie River to the Quiver River to increase the amount of surface water available in the Quiver River, thus decreasing the need for groundwater pumping (fig. $6 D$ ). This scenario was analyzed with six sub-scenarios representing three different rates of adoption and two different areas of availability adjacent to the Quiver River. The rates of adoptions were assumed to be either 100, 66 , or 33 percent. The Quiver River as an alternate source was 
Water-level change hydrographs by model scenario

$\boldsymbol{A}$

Irrigation efficiency

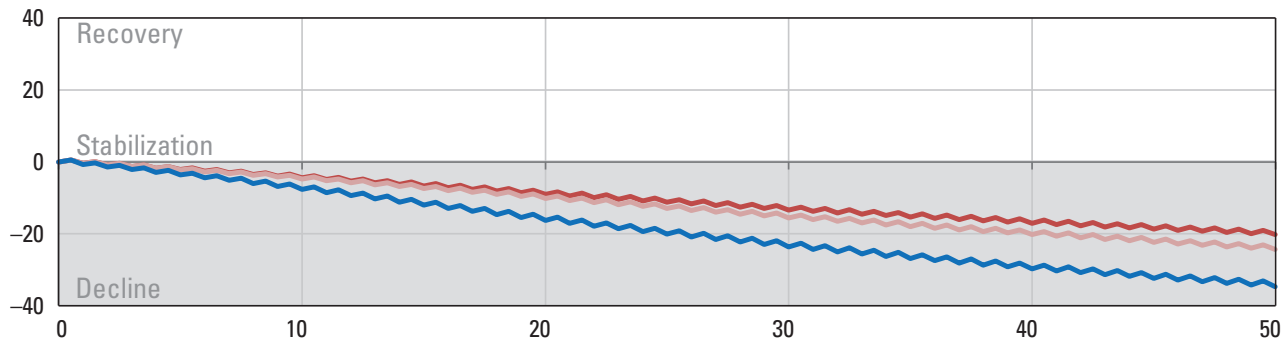

EXPLANATION

Entire Delta

Central Delta

Base

B

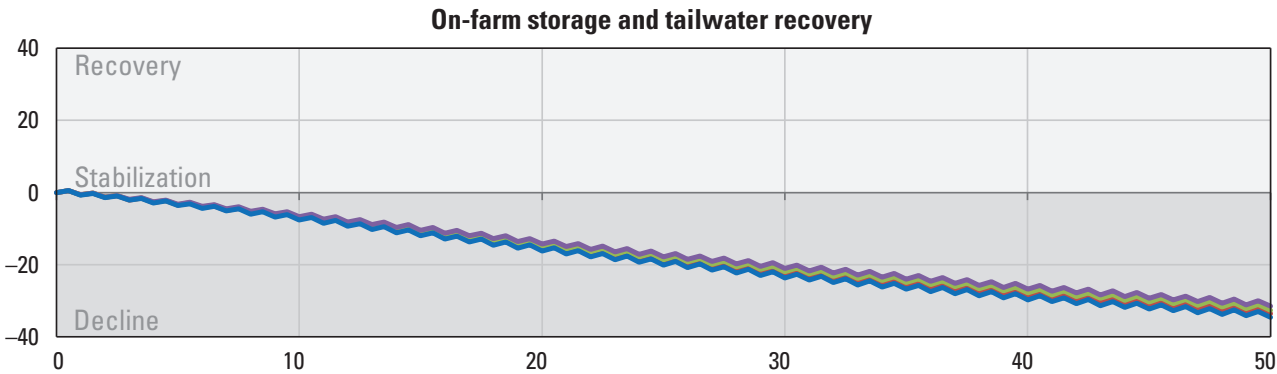

- Entire Delta, 25 percent reduction

Entire Delta, 50 percent reduction

Entire Delta, 75 percent reduction

Base

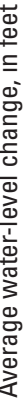
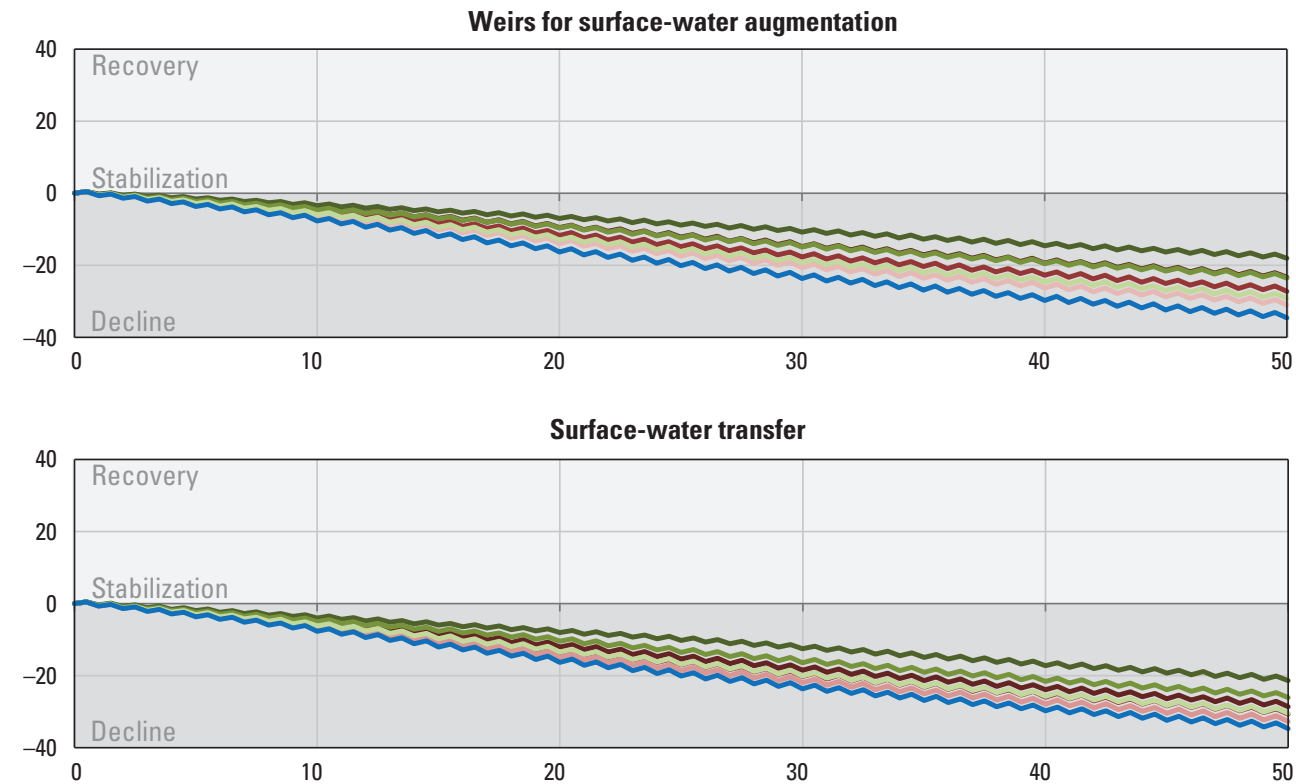

E

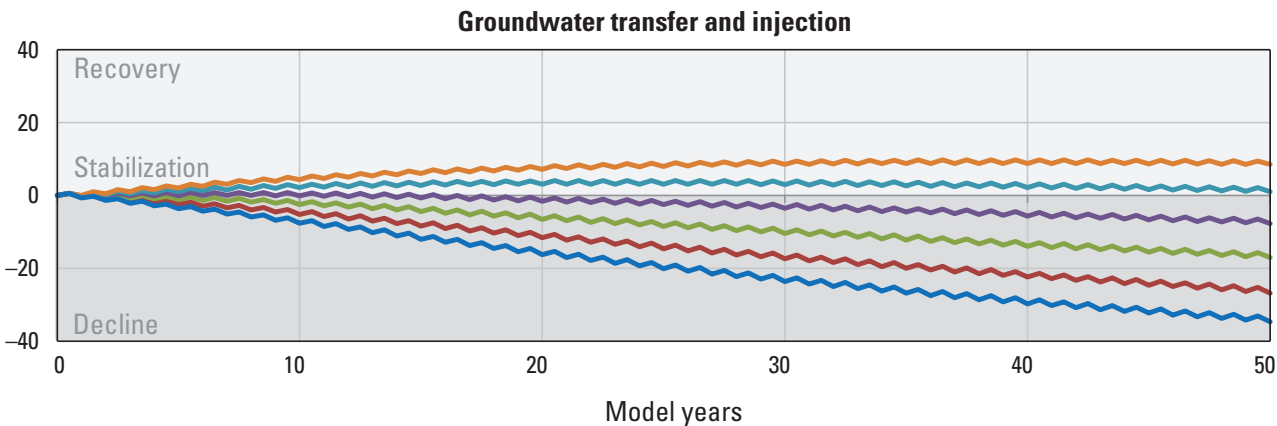

$15,000 \mathrm{gal} / \mathrm{min}$ transferred

30,000 gal/min transferred

$45,000 \mathrm{gal} / \mathrm{min}$ transferrec

$60,000 \mathrm{gal} / \mathrm{min}$ transferred

$75,000 \mathrm{gal} / \mathrm{min}$ transferred

Base

gal/min = gallons per minute

Figure 7. Water-level change for each scenario: $A$, irrigation efficiency, $B$, on-farm storage and tailwater recovery, $C$, instream weirs, $D$, surface-water transfer, and $E$, groundwater transfer and injection. 


\section{Simulation of Water-Management Scenarios for the Mississippi Delta}

Table 2. Summary of selected alternative water-management scenario assumptions and results within area of interest ${ }^{1}$ in the Mississippi Delta.

[\%, percent; mi, mile; gal $/ \mathrm{min}$, gallon per minute]

\begin{tabular}{|c|c|c|c|c|c|}
\hline $\begin{array}{l}\text { Water-management } \\
\quad \text { scenario }\end{array}$ & Sub-scenario & Type of change & $\begin{array}{l}\text { Volume of water not } \\
\text { pumped or added } \\
\text { directly, in acre-feet } \\
\text { per year }\end{array}$ & $\begin{array}{l}\text { Average increase in } \\
\text { water level above base } \\
\text { scenario within the } \\
\text { central Delta area' at } \\
\text { year } 50 \text {, in feet }\end{array}$ & $\begin{array}{l}\text { Average increase in } \\
\text { water level above base } \\
\text { scenario within the } \\
\text { central Delta area' at } \\
\text { year } 50 \text {, in percent }\end{array}$ \\
\hline \multirow{2}{*}{$\begin{array}{l}\text { Irrigation efficiency } \\
\text { (specified reduction } \\
\text { by crop) }\end{array}$} & Delta-wide & \multirow{2}{*}{$\begin{array}{l}\text { Decrease } \\
\text { groundwater } \\
\text { withdrawals }\end{array}$} & 530,647 & 15 & 42 \\
\hline & Central Delta & & 36,710 & 11 & 30 \\
\hline \multirow[t]{3}{*}{$\begin{array}{l}\text { On-farm storage and } \\
\text { tailwater recovery }\end{array}$} & $\begin{array}{l}25 \% \text { reduction } \\
\text { (Tailwater re- } \\
\text { covery only) }\end{array}$ & $\begin{array}{l}\text { Decrease } \\
\text { groundwater } \\
\text { withdrawals }\end{array}$ & 18,432 & 1 & 3 \\
\hline & $\begin{array}{l}50 \% \text { reduction } \\
\quad \text { Mix of tail- } \\
\text { water recovery } \\
\text { with and with- } \\
\text { out on-farm } \\
\text { storage) }\end{array}$ & & 36,865 & 2 & 6 \\
\hline & $\begin{array}{l}\text { 75\% reduction } \\
\text { (Tailwater } \\
\text { recovery and } \\
\text { on-farm stor- } \\
\text { age) }\end{array}$ & & 55,297 & 3 & 9 \\
\hline \multirow[t]{6}{*}{$\begin{array}{l}\text { Instream weirs for } \\
\text { surface-water avail- } \\
\text { ability }\end{array}$} & $\begin{array}{l}33 \% \text { adoption } \\
\text { (1/2-mi buffer } \\
\text { area) }\end{array}$ & $\begin{array}{l}\text { Decrease } \\
\text { groundwater } \\
\text { withdrawals }\end{array}$ & 24,186 & 4 & 11 \\
\hline & $\begin{array}{l}66 \% \text { adoption } \\
(1 / 2 \text {-mi buffer } \\
\text { area) }\end{array}$ & & 48,372 & 7 & 21 \\
\hline & $\begin{array}{l}\text { 100\% adoption } \\
\text { (1/2-mi buffer } \\
\text { area) }\end{array}$ & & 73,290 & 12 & 33 \\
\hline & $\begin{array}{l}\text { 33\% adoption } \\
\text { (3/4-mi buffer } \\
\text { area) }\end{array}$ & & 35,923 & 6 & 16 \\
\hline & $\begin{array}{l}\text { 66\% adoption } \\
\text { (3/4-mi buffer } \\
\text { area) }\end{array}$ & & 71,847 & 11 & 32 \\
\hline & $\begin{array}{l}\text { 100\% adoption } \\
\text { (3/4-mi buffer } \\
\text { area) }\end{array}$ & & 108,859 & 17 & 48 \\
\hline
\end{tabular}


Table 2. Summary of selected alternative water-management scenario assumptions and results within area of interest ${ }^{1}$ in the Mississippi Delta.-Continued

[\%, percent; mi, mile; gal $/ \mathrm{min}$, gallon per minute $]$

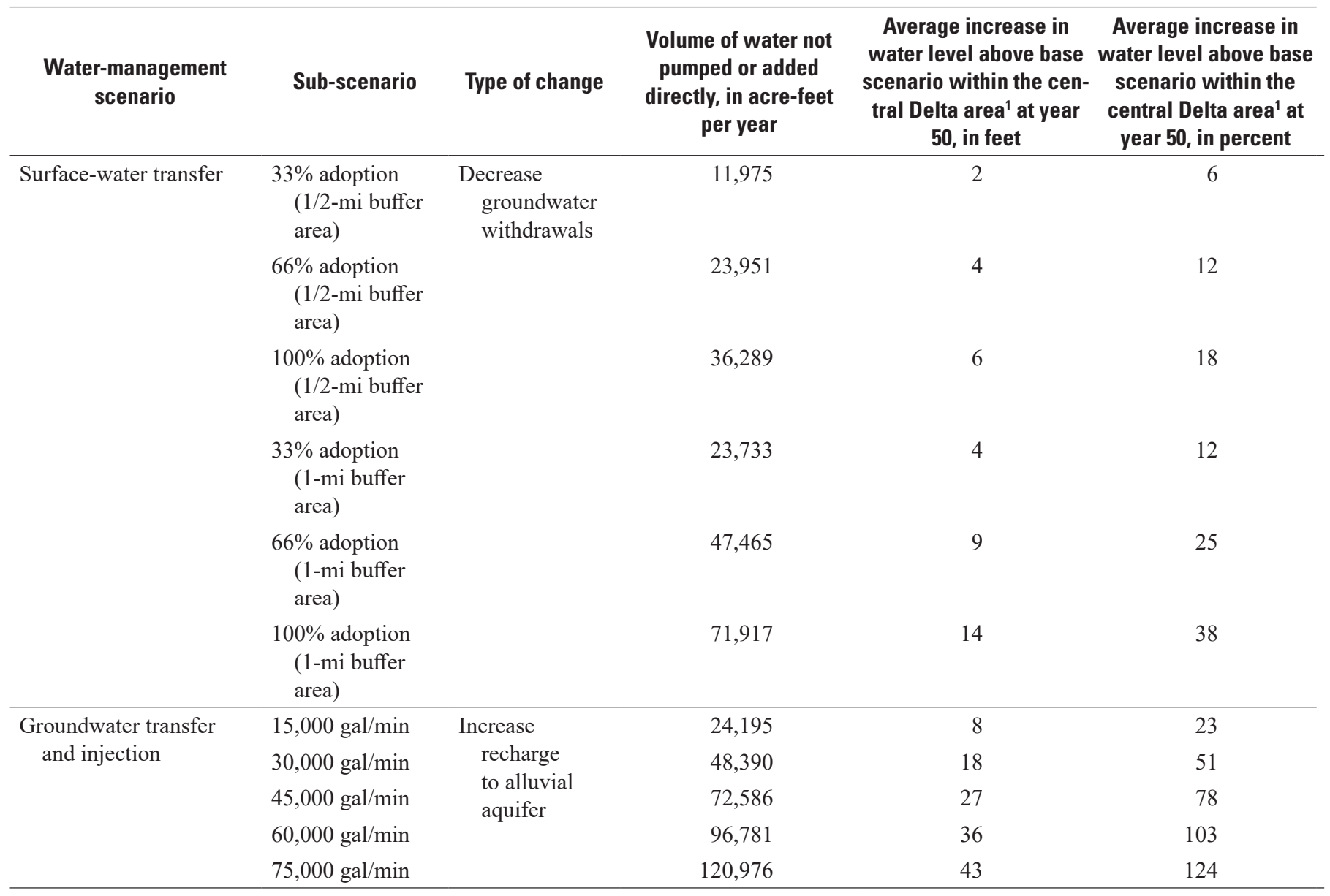

${ }^{1}$ See figure 6 for location of central Delta/composite hydrograph area.

assumed to be available within either a $1 / 2$-mi or 1 -mi buffer area adjacent to the affected reach of the Quiver River. A sufficient supply of water was assumed for all sub-scenarios.

The total change or decline in the average water level over the 50-year simulation for this scenario, assuming availability within $1 / 2$ mile of the Quiver River, ranges from about 29 to $33 \mathrm{ft}$, or 2 to $6 \mathrm{ft}$ less than the decline of $35 \mathrm{ft}$ for the base scenario, depending on the adoption rate assumed (fig. 7D; table 2). The total change or decline in the average water level over the 50-year simulation for this scenario, assuming availability within $1 \mathrm{mi}$ of the Quiver River, ranges from about 21 to $33 \mathrm{ft}$, or 4 to $14 \mathrm{ft}$ less than the decline of $35 \mathrm{ft}$ for the base scenario, depending on the adoption rate assumed (fig. 7D; table 2).

\section{Groundwater-Transfer and Injection Scenario}

The groundwater-transfer and injection scenario assumes withdrawal wells located along the Tallahatchie River can be used as a source of water that is then pumped to the central Delta area and injected into the alluvial aquifer (Dr. J.R. Rigby, U.S. Department of Agriculture, Agricultural Research Service, written commun., 2016; fig. 6E). This scenario was analyzed with five sub-scenarios representing different watertransfer rates. The rates of water transfer were assumed to be constant at 15,000 gallons per minute ( $\mathrm{gal} / \mathrm{min}), 30,000 \mathrm{gal} /$ $\mathrm{min}, 45,000 \mathrm{gal} / \mathrm{min}, 60,000 \mathrm{gal} / \mathrm{min}$, and 75,000 gal $/ \mathrm{min}$.

The maximum water transfer rate of $75,000 \mathrm{gal} / \mathrm{min}$ is a small percentage of the flow in the Tallahatchie River as measured by the USGS streamgage on the Tallahatchie River at Money, MS (USGS station no. 07281600), which 
has a drainage area of 5,221 $\mathrm{mi}^{2}$ (USGS, 2018; fig. 6E). For water years 1996 through 2016, the annual mean flow on the Tallahatchie River at Money, MS (USGS station no. 07281600 ) ranged from $3,490 \mathrm{ft}^{3} / \mathrm{s}$ in 2000 to $12,830 \mathrm{ft}^{3} / \mathrm{s}$ in 2003. The maximum transfer rate of $75,000 \mathrm{gal} / \mathrm{min}\left(167 \mathrm{ft}^{3} / \mathrm{s}\right)$ ranges from 1.3 to 4.8 percent of the annual mean flow. For water years 1996 through 2016, the daily mean flows on the Tallahatchie River at Money, MS (07281600) ranged from $585 \mathrm{ft}^{3} / \mathrm{s}$ on September 6, 2007, to $20,600 \mathrm{ft}^{3} / \mathrm{s}$ on February 1, 2010. The maximum transfer rate of $75,000 \mathrm{gal} / \mathrm{min}\left(167 \mathrm{ft}^{3} / \mathrm{s}\right)$ ranges from 0.8 to 28.5 percent of the daily mean flow. There are no days when the maximum transfer rate exceeds the daily mean flow.

The total change in the average water level over the 50 -year simulation for this scenario ranges from a decline of about $27 \mathrm{ft}$ to an increase of about $8 \mathrm{ft}$, or 8 to $43 \mathrm{ft}$ less decline than the $35-\mathrm{ft}$ decline in the base scenario, depending on the water-transfer rate (fig. $7 E$; table 2).

\section{Model Limitations}

Models are simplifications of natural systems. Factors that affect how well a model represents a given natural system include the model scale, the accuracy and availability of hydrogeologic property data, the accuracy of withdrawal, water-level and streamflow data, and appropriately defined boundary conditions. The MERAS model, used for the analysis presented in this report, is consistent with the conceptual model and hydrologic data of the MERAS study area. The MERAS model uses a grid-cell size of $1 \mathrm{mi}^{2}$, and a model will not provide accurate prediction on a scale smaller than the grid resolution. The hydraulic-conductivity zones used in the MERAS model represent large-scale variation in hydraulic properties; the actual spatial variations of hydraulic properties of the aquifer system occur on a much smaller scale and are not defined in great detail. Further discussion of the limitations of the MERAS model are reported by Clark and Hart (2009, p. 56).

\section{Summary}

The U.S. Geological Survey and the Mississippi Department of Environmental Quality are collaborating on the update and enhancement of an existing regional groundwaterflow model to evaluate selected alternative water-supply scenarios and identify data needs for future water management and modeling efforts in the Mississippi Delta. Alternative water-supply options assessed to date include (1) irrigation efficiency; (2) on-farm storage and tailwater recovery; (3) instream weirs to increase surface-water availability; (4) intrabasin transfer of surface-water to increase surface-water availability; and (5) groundwater transfer and injection. A relative comparison approach was used in which the water-level response resulting from each scenario was calculated by taking the difference between water levels predicted by each alternative water-supply scenario and a base, or "no action," scenario. Although the calculated water-level response is positive for each scenario, it does not indicate that water levels are increasing relative to initial conditions, rather that the water levels in the alternative scenario are relatively higher than those in the base scenario. Water-level response in the alluvial aquifer varied for each scenario based on the location and adoption rate of the implemented alternative-supply option. These initial model results serve as a starting point to develop and assess conjunctive water-management-optimization scenarios, as well as to improve and enhance current and future monitoring activities within the Delta.

\section{Selected References}

Arthur, J.K., 2001, Hydrogeology, model description, and flow analysis of the Mississippi River alluvial aquifer in northwestern Mississippi: U.S. Geological Survey WaterResources Investigations Report 01-4035, 47 p.

Arthur, J.K., and Taylor, R.E., 1990, Definition of the geohydrologic framework and preliminary simulation of groundwater flow in the Mississippi embayment aquifer system, Gulf Coastal Plain, United States: U.S. Geological Survey Water-Resources Investigations Report 86-4364, 97 p.

Barlow, J.R.B., and Clark, B.R., 2011, Simulation of water-use conservation scenarios for the Mississippi Delta using an existing regional groundwater flow model: U.S. Geological Survey Scientific Investigations Report 2011-5019, 14 p.

Clark, B.R., and Hart, R.M., 2009, The Mississippi Embayment Regional Aquifer Study (MERAS) Documentation of a groundwater-flow model constructed to assess water availability in the Mississippi embayment: U.S. Geological Survey Scientific Investigations Report 2009-5172, 61 p.

Clark, B.R., Hart, R.M., and Gurdak, J.J., 2011, Groundwater availability of the Mississippi embayment: U.S. Geological Survey Professional Paper 1785, 62 p.

Clark, B.R., Westerman, D.A., and Fugitt, D.T., 2013, Enhancements to the Mississippi Embayment Regional Aquifer Study (MERAS) groundwater-flow model and simulations of sustainable water-level scenarios: U.S. Geological Survey Scientific Investigations Report 2013-5161, 29 p., accessed May 26, 2017, at https://pubs.usgs.gov/sir/2013/5161/. 
Economic Research Service, U.S. Department of Agriculture, 2010, The economics of food, farming, natural resources, and rural America - State fact sheets-Mississippi, accessed January 20, 2011, at http://www.ers.usda.gov/ StateFacts/MS.htm.

Fisk, H.N., 1944, Geological investigation of the alluvial valley of the lower Mississippi River: U.S. Department of Army, Mississippi River Commission, 78 p.

Harbaugh, A.W., 2005, MODFLOW-2005, the U.S. Geological Survey modular ground-water model-The ground-water flow process: U.S. Geological Survey Techniques and Methods 6-A16, variously paged.

Hart, R.M., Clark, B.R., and Bolyard, S.E., 2008, Digital surfaces and thicknesses of selected hydrogeologic units within the Mississippi Embayment Regional Aquifer Study (MERAS): U.S. Geological Survey Scientific Investigations Report 2008-5098, 33 p.

Haugh, C.J., Killian, C.D., and Barlow, J.R.B., 2020, MODFLOW-2005 model used to evaluate water-management scenarios for the Mississippi Delta: U.S. Geological Survey data release, https://doi.org/10.5066/P9906VM5.

Hosman, R.L., 1988, Geohydrologic framework of the Gulf Coastal Plain: U.S. Geological Survey Hydrologic Investigations Atlas 695, 2 sheets.
Massey, J.H., Stiles, C.M., Epting, J.W., Powers, R.S., Kelly, D.B., Bowling, T.H., Janes, C.L., and Pennington, D.A., 2017, Long-term measurements of agronomic crop irrigation in the Mississippi Delta portion of the Lower Mississippi River Valley: Irrigation Science, v. 35, no. 4, p. 297-313, accessed May 30, 2016, at https://doi.org/ 10.1007/s00271-017-0543-y.

Maupin, M.A., and Barber, N.L., 2005, Estimated withdrawals from principal aquifers in the United States, 2000: U.S. Geological Survey Circular 1279, 46 p.

Miller, B.V., Wallace, D.S., and Kress, W.H., 2016a, Waterborne continuous resistivity profiling data from select streams of the Mississippi Alluvial Plain in northwestern Mississippi: U.S. Geological Survey data release, accessed December 21, 2016, at https://doi.org/10.5066/F7FT8J68.

Miller, B.V., Wallace, D.S., and Kress, W.H., 2016b, Waterborne continuous resistivity profiling data from select streams of the Mississippi Alluvial Plain in northwestern Mississippi [abs.]: AGU Fall Meeting, December 2016.

PRISM Climate Group, 2015, PRISM Group, accessed January 12, 2015, at http:/www.ocs.orst.edu/prism/.

U.S. Geological Survey [USGS], 2018, USGS water data for the Nation: U.S. Geological Survey National Water Information System database, accessed November 9, 2018, at https://doi.org/10.5066/F7P55KJN.

Yazoo Mississippi Delta Joint Water Management District, 2016, Annual summaries, accessed May 30, 2016, at http://www.ymd.org/publications.htm.

For more information about this publication, contact Director, Lower Mississippi-Gulf Water Science Center U.S. Geological Survey 640 Grassmere Park, Suite 100 Nashville, TN 37211

For additional information, visit https://www.usgs.gov/centers/lmg-water/

Publishing support provided by Lafayette Publishing Service Center 



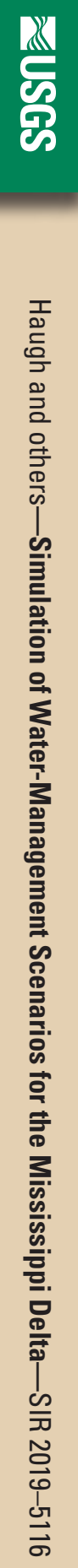